\title{
Police Officers' Discourse on Social Networking Sites Surrounding High-Profile Cases
}

\author{
Samantha Okegbe \\ Department of Communication, University of Illinois at Urbana-Champaign \\ 702 S. Wright St. Urbana, Illinois, 61801, USA
}

\begin{abstract}
Research on police officers' attitude towards the use of excessive force have not been studied fully. Several studies have focused on their behavior than their attitudes towards excessive force. The on-going pandemic raised renewed interest in the persistent issue of police brutality in the United States. The paper presents online conversations of police officers revealing their opinions towards officers use of excessive force. This paper provides some groundwork for future researchers by examining police officers discourse online. The paper concludes with discussion and implications for law enforcement agencies and the safety of the society.
\end{abstract}

Keywords: Discourse, police officer, social media, police brutality, COVID-19

DOI: $10.7176 / \mathrm{JEP} / 12-36-10$

Publication date: December $31^{\text {st }} 2021$

Worldwide, the issue of police brutality and social injustice has become a controversial topic in recent times. One of the few issues that triggers a society to react more than the issue of race, is the issue of police (Glover, 2007). Evidence of violent police-citizen encounters explains the disparities between the police and the public (Lersch \& Feagin, 1996; Neocleous, 2000). In the United States, there are a number of recent high profile cases involving police brutality and cases of racial profiling such as the shooting of Breonna Taylor, an African-American emergency technician in her home; the fatal shooting of Ahmaud Arbery, an unarmed African-American boy while jogging; and the killing of George Floyd by a police officer who knelt on his neck for eight minutes till he died. In the wake of the COVID-19 pandemic, these high-profile incidents sparked a huge media attention provoking people into protest demonstrations. These protests occurred to stand against police brutality and to hold these officers accountable under the law. Although there is a lot of growing literature concerning police brutality and the public's perception towards the police (Chow, 2012; Jackson \& Bradford, 2019; Klein et al, 1978; Tuch \& Weitzer, 1997, Weitzer, 2002), there has been a relatively lack of empirical research examining police attitude and police discourse in online platforms. This paper aims to examine police account towards excessive or unnecessary use of force by exploring their online discourse surrounding high profile cases. With an increase in the rise of police brutality, social injustice, and racial inequality, it is important to explore how police discuss such issues on social media. To this day, little or no research exist examining police officers' online conversations surrounding highprofile cases. Only few studies has examined police organizations and their communications using social media.

In contemporary times, an existing issue of the police-minority relationship is police brutality and police unaccountability. The use of excessive and unnecessary force by police officers without penalties is still prevalent. Studies reveal that police officers feel justified to use excessive force if the situation warrants it (Adams, 1999). Other studies report majority of officers do not support the use of unnecessary force (Micucci \& Gomme, 2005). Findings from the report reveal novice officers with little experience and senior veterans with greater experience consider the use of excessive force a serious violation. This is in contrast with their intermediate counterparts who viewed the use of excessive force as a less serious violation.

Research shows that police officers engage in some form of story-telling and sharing of experiences when they are not actively engaged in police work (Van Hulst, 2013). This helps foster socialization of officers and may lead to further discussions and interactions online. The current explosion of social networking sites like Facebook, Twitter, Instagram, and many others has made more data available for social scientist (Procter et al., 2013). These social media discussions creates an avenue that has not been fully explored by scholars. It is important we analyze police discourse concerning issues of police brutality as it provides their personal perspectives on these issues and what ideologies they hold. It also gives us insight into their personal views and attitudes especially if it varies from the views of their police organizations. Analyzing police officers' discourse may also provide context for their behaviors and understanding their attitudes towards these high-profile cases. This study helps give insight to police account of police brutality and police accountability in times of social unrest and injustice.

\section{Understanding police use of excessive force}

The recent deaths of citizens in the hands of police has provoked strong reactions and national discourse from the public and law enforcement agencies. This current study focuses on the discourse of police officers on social media platforms concerning high-profile cases of police brutality. It is vital we gain some understanding behind the police use of excessive or unnecessary force. The police are mandated to use violence as part of their duty to maintain 
social order in the society (Manning, 1980). The public and the police differ in their views about some aspects of policing (Morin et al., 2017). For example, concerning the opinions of the public and police on the deaths of blacks in the hands of the police, a pew research study revealed that $67 \%$ of the police and only $39 \%$ of the public consider these as isolated incidents and not as signs of a broader problem between the police and blacks (Morin et al., 2017). Levels of police force has been assessed as police presence, verbal commands, restrained forcibly, deadly force, and non-deadly force (Alpert \& Dunham, 1997). It is common for the public not to react to the police use of force except in unique situations where the action of violence is strongly visible (Manning, 1980). In recent times, the public seems to be taking an active role in observing the actions of the police and protesting the use of brutal force. These violent actions by the police are commonly recorded and posted on social media platforms. The videos are shared multiple times on these platforms and goes viral, triggering massive reactions from viewers.

There is not an agreed upon definition among scholars and police institutions for terms like excessive force, brutality, unjustified force, misuse of force, and unnecessary force (Phillips \& Sobol, 2011; Terrill \& Mastrofski, 2002). These terms are not easy to define and are used interchangeably to describe the use of violence by the police. Brutality is damage that may be physically or mental that is devoid of humane feelings (Adams, 1999). Fyfe (1986) described brutality as a willful and conscious use of force. Adams considers excessive force as the use of force beyond required by the law of the institution. This form of force is considered improper or illegitimate and the officers right to use force has been mishandled. Other scholars consider excessive force as the use of unnecessary force to gain compliance which may occur before or after a citizen's resistance and force as that required to subdue a citizen (Adams, 1999; Worden, 1995).

Despite the growing use of social media by police organizations to communicate with the public, very few studies has focused on the effectiveness of this form of communication (Crump, 2011; Hu et al., 2020). Several scholars have conducted studies to examine police officer's opinions on the use of excessive force. Muir (1997) conducted a study based on observations of officers. He found out that officers with little empathy towards citizens and those who felt the use of force was acceptable were more likely to use excessive force. The assumption is that an officer's views may affect their actions and their likelihood to exert force on duty. In Klockars et al. (2000) study, they examined police opinion towards the use of excessive force, using a scenario-based survey instrument. Respondents from 30 different police agencies responded negatively to the use of excessive force. Scholars have also conducted studies to examine how police officers in other countries responded to the use of excessive force. For example, Novak and Ivkovic (2005) examined police officers from the United States, Croatia, and Finland and their attitudes towards the use of force. Findings show that respondents from the US and Finland considered the use of excessive force on a fleeing car thief to be more serious issue than what the Croatian respondents considered. Studies show that the level of willingness of officers to report other officers use of excessive force were low (Ekenvall, 2003). One reason is that the officer who reported the misconduct is likely to get the cold shoulder from other officers (Weisburd \& Greenspan, 2000). However, majority of police officers would report the use of excessive force to a fellow officer (Klockars et al., 2000). This may explain the likelihood of officers discussing issues involving the police misconduct like racial profiling, and unjustified shootings.

There are different views on the determinants of police use of force. Police officers use of force changes by "who the citizen is" and "what the citizen does" (Terrill \& Mastrofski, 2002). They add that officers are expected to respond to citizens actions and not their traits. But officers have been found exerting unnecessary force based on "who the citizen is." For example, marginalized groups like the youths, the poor, and racial minorities continue to receive unfair treatment (Terrill \& Mastrofski, 2002). A second view associates an officers' individual characteristics or views as influencing their use of coercion. This means that officers with a type of trait, beliefs, background, perspectives, or experiences will respond a certain way in a certain situation. These differences in attitudes and views will determine an officer's likelihood of employing excessive forceful practices (Cohen \& Chaiken, 1972; Worden, 2015). Some of these views may be expressed on their social media platforms with friends, family, and strangers. Other scholars also found situational determinants to be strongly associated with police use of force (Worden, 2005).

\section{Online Platforms}

Online discussion forums are virtual spaces that help facilitate dialogue among people. These voluntary spaces are a universe of discourse and are referred to as "the commons" (Brainard \& Derrick-Mills, 2011). They comprise of groups of people who have a common understanding, share common language, and develop a culture or community over time. A commons may be either offline, online or both (Brainard \& Derrick-Mills, 2011). They add that this universe of discourse is what brings people together. When individuals have certain views and beliefs, they tend to share those views on their social media platforms in the form of Facebook posts, tweets, status updates, sharing Tik Tok videos, or snaps. Other times, they share their views with certain groups of people who share similar views. Social media platforms one of those common virtual spaces where people start a public conversation, follow a thread of conversations, or make comments concerning specific topics. Nonetheless, one of the major concerns of police organizations about the use of social networking services is the fear of their employees posting 
inappropriate content and damaging the organizations image (Stephens, 2010). One way this has been addressed is through internal policies that highlight expected behaviors of police officers when interacting online. This study looks at the social networking platforms like Facebook, Twitter, Instagram, and Tik Tok due of the ease of accessing public data on people's conversations. The empirical basis of this study is to analyze these social media posts and comments by police officers account on police brutality in high-profile cases. Some of these posts includes text, images and videos which will be included in the data for analysis.

The widespread use of social media has led scholars to examine the use of these platforms. However, little if any research has been conducted examining individual police officers use of social media to discuss high-profile cases. A few of the studies that exist examines the use of social media by city police departments. The few studies that exist on this topic include Twitter (Crump, 2011; Haverin \& Zach, 2010; O’Conner, 2017; Procter et al., 2013; Schneider, 2016). Some other studies examined the use of Facebook (Dai et al., 2017; Hu et al., 2018; Kelly, 2014; Libermann et al., 2013).

\section{Police discourse online}

Enforcement agencies around the country are concerned with their employees use of social media and how to set up policies to restrict offensive speech online without restricting their first amendment rights. Scholars have focused their research on how these agencies create and maintain their image online, but little research has focused on how these officers present themselves online. Comments posted online have led to officers facing disciplinary actions such as paid leave, suspension, administrative leave, and being fired. An examination of officers' public social media posts reveals comments they made in relation to high-profile incidents.

A north Alabama police officer, Ross Greenwood, was placed on administrative leave for sharing two images via a Facebook post. One of the posts shows an image of George Floyd on a \$20 bill with a statement, "The Treasury Department will honor George Floyd by placing his portrait on the Counterfeit \$20 Bill." The other shows Quaker oats brand image beside an image of Floyd wearing the same regalia and states, "BREAKING NEWS: Quaker Oats officially changes name to Shaquille O'atmeal." The shared post seems to be mocking George Floyd. The case is still being investigated at this time. However, the officer does not find anything wrong with the post and continues to leave it on his Facebook profile (Koplowitz, 2020). Find image of post in Appendix I.

A Troy University chief of police, John McCall, was suspended over a now-deleted inflammatory comments he made on Facebook concerning George Floyd (Gore, 2020). Screenshots of the post were shared by a Troy university student leading to the screenshots becoming viral. The officer seems to blame Floyd solely responsible for his demise. In the post, officer McCall commented,

"...more whites are killed by police every year! Where is the media screaming about that? People die in police custody from time to time. Did the officer make a mistake? Yes. Does he regret it? Yes. Was he intentionally trying to kill George Floyd? I don't think so. Did George Floyd paly any role in his own death? ABSOLUTELY! He fought with the police who were trying to make a lawful arrest..." (Find full comment in Appendix I).

A Mocksville police officer was placed on administrative leave after sharing a post on social media about George Floyd (McKenith, 2020). According to a spokesperson for the police department, the officer shared a Facebook post portraying an image of George Floyd and added a text stating he committed a criminal offense against a pregnant woman. The officer re-shared the post and added a comment stating, "And don't forget (he) raped [sic] her!" The Mocksville police department later released a statement to the public,

"We do not condone or agree with this employee's social media statements," the department said Tuesday. The Mocksville Police Department is dedicated to serving its citizens with transparency and equality. The role of law enforcement must always be fair, just, and unbiased. These social media exchanges by the employee do not reflect the beliefs of the Mocksville Police Department or the Town of Mocksville. We cannot and will not tolerate any language, behavior, or associations that would allow for a disruption in our agency's moral code. For that reason, the employee in question has been placed on administrative leave pending an investigation."

A Louisville Metro Corrections officer was suspended for a Facebook post showing her support for the confederate flag and a post that seems to be criticizing Floyd (Riley, 2020). In the shared post showing some of his criminal records, she commented:

"well look what I found about George Floyd. He was such a saint alright. It would be a shame if this went viral." In another post the officer shared about the confederate flag, she stated "Slavery is a choice and the flag is not about race, it's about freedom." In another post she shared, it stated, "If we had equal rights in this country, won't my Southern heritage be just as important as your black history?"

In the wake of the protest over police brutality and the killing of Floyd, a Denver police officer was fired over an Instagram post captioned "Let's start a riot" (Schmelzer, 2020). He posted the photo of himself and two other officers wearing riot gear and added the caption (Find post in Appendix I). According to the statement released by the Denver Police Department, he violated the department's social media policy. 
A Greenbrier officer shared an inflammatory post on his Facebook and later resigned because of it (Mitchell, 2020). Officer Corey Tidwell posted:

"If he (Floyd) was $* * * * * *$ begging he was $* * * * * *$ breathing- the same old bull**** over and over and over."

A Wayne country police officer, Jeff Lewis shared his opinion concerning the George Floyd killing (Morgan, 2020). The now deleted post went viral and screenshots of the post were shared multiple times on social media by people who were upset about the post. In the Facebook post, he added a photo of the officer kneeling on Floyd's neck and added,

"Here's where I lose more "friends". Oh no... Whitey killed a black man. Nobody has a clue what lead up to this. Everyone has their MEDIA FORCED OPINION. Clearly this black man had the covid and that officer was preventing the spread."

A Chattanooga police chief, tweet went viral after he shared his views about the killing of Floyd (Hayes, 2020). In the viral tweet, he included a snapshot of the police officer kneeling on the neck of Floyd and added, "There is no need to see more video. There no need to wait to see how "it plays out". There is no need to put a knee on someone's neck for NINE minutes. There IS a need to DO something. If you wear a badge and you don't have an issue with this...turn it in." Find full post in Appendix I

A Chief Deputy also shared his opinion on the issue (Hayes, 2020). He tweeted that,

"As leaders our communities must know where we stand. This act of violence is black \& white. Make no mistake, there's no explanation or gray in it. For 8 min George Floyd lay suffocating and dying. If you wear a badge stand up for what's right \& stand up \& speak out against wrong."

A former Chattanooga police weighed in on the issue through Twitter (Hayes, 2020). He tweeted,

"Those of us from LE have duty to stand up \& speak out \& act against injustices large \& small in our profession - long before they become murder. I see many of u who do stand up \& act - lets magnify their influence."

A viral video compilation from a Facebook account "It's Gone Viral" shared some videos of officers speaking up in support of George Floyd. In the video clips, the officers were very vocal in calling Floyd's death a murder and accused the officers involved of being solely responsible. A Georgia patrol officer, posted a Tik tok video that went viral. In the video, he stated,

"I am disgusted with the things that happened in Minneapolis. Pure, point blank, things could have went way different. At the end of the day, let's talk facts. Guy is on the ground. He's laying on his stomach. He has handcuffs on. It's four of y'all, one of him. Four of y'all, one of him. Who has control of the situation? As an officer, you are a first responder, right? So if in the midst of you trying to gain compliance someone is hurt, you have to render aid. So, somebody saying "I can't breathe, I can't breathe," you don't think to yourself and say "Oh my gosh, this guy can't breathe, he might die. If I see wrong happening, wrong is not happening in my presence, right? I'm going to check it. And that's period!"

In another viral video, a Texas sergeant Pablo stated,

"The man was murdered. Nowhere in mechanics of arrest are we ever taught to put our knees on to somebody's neck/throat area, especially for that long! And the three officers standing around watching that happen, y'all are at fault too. Y'all could have told the man 'get off him he can't breathe.' I mean you're hearing him say it. It should have never gone that way. Rest in peace, George Floyd.”

A detective in Utah, Lystrup posted a video weighing in on the Floyd issue. In the video, he stated,

"I've seen the video of George Floyd's murder. That's what I believe it was, it was murder by a police officer. And I'm not okay with that. I am not okay with somebody in my profession doing something like that to another human being. The man goes unconscious and they don't even provide CPR or aid to him? They continue to kneel on him? That is NOT okay! And if you as a police officer can watch that video and not think something's wrong? You are part of this problem. You don't admit when somebody did something wrong. George Floyd's family, I'm sorry. This was not okay."

A deputy officer in Louisiana, Herbert stated in a video clip that went viral,

"So I got a chance to watch this video of George Floyd being murdered on the streets of Minnesota. Yeah. Murdered. And we have an obligation as good officers to speak out against the bad. We have an obligation and we owe it to the public and to the other officers in this country that are out here actually trying to do good. Actually trying to protect and serve with honor. And if you stay quiet and don't speak out against it because of your fear of judgement? You're complicit in the behavior. The disgusting behavior. It's time that we take these bad officers and speak out against them and start holding them accountable and hold them to the same laws that we expect citizens to abide by. They're not above it and it's time that good officers start speaking out and stopping it."

An Indiana patrol officer, Doug posted a video stating,

"To the Floyd family, I am truly sorry for your loss. And that should have never happened. And I hope those people are found to be guilty of murder. Cause that's what that was. We gotta change this. We gotta 
break these barriers and these walls and we gotta do what we can as police officers. So five years ago, I did a traffic stop where a young man thought I was gonna hurt or kill his dad because of the color of his skin and that broke my heart. And from that moment on I decided to change the way I do policing. I let them see who I am underneath this vest and who I am underneath this badge. So the innocent people don't have to fear me anymore. Because that's not what we signed up for. So I challenge the other law enforcement officers, get out of your car and get to know the people you protect."

\section{Conclusion and Implications}

An examination of online discourse by police officers is important in understanding public issues such as police practices, social injustice, police misconduct, public safety, and fair administration of the law. A limitation of the study may be the small amount of data collected of police officer's discourse online. Nevertheless, this study starts the groundwork of the limited literature that examines police officer's attitude and discourse online.

One implication of this study for law enforcement agencies is providing online sites for a private online discussion group for officers. A safe place where they can express themselves from the watchful eyes of the public. The police department should continue to implement online discussion forums between citizens and the police to foster socialization and a sense of community to bridge the gap between the police and the society (Brainard \& Derrick-Mills, 2011). Social media managers should be employed to manage and monitor officer's comments and their social media presence (Hughey \& Daniels, 2013; Waters, 2012). They should pay attention to their officer's social media conversation as this will help mitigate against potential problems for the organizations.

This study may also have implications for policy makers. Policies should be made to ensure awareness training on racism in the police department. These training should encourage open discussions where everyone feels safe to express their opinions and are aware of racial stereotypes and alternative ways to make an arrest (Turchan, 2020). This will prevent the constant use of unnecessary force. This study will add to the growing volume of literature on police discourse on social media. It will also provide an understanding of police views and opinions towards social issues. This sheds light on some groundwork for future researchers who may be interested in examining police discourse online. One of the most surprising finding is the lack of literature examining police discourse online at the individual level. Future research may examine a wider range of police officers' conversations on social media.

\section{References}

Adams, K. (1999). Use of force by police: Overview of national and local data. US Department of Justice, Office of Justice Programs, National Institute of Justice.

Alpert, G. P., \& Dunham, R. G. (1997). The force factor: Measuring police use of force relative to suspect resistance. Washington, DC: Police Executive Research Forum.

Bonilla-Silva, E. (2001). White supremacy and racism in the post-civil rights era. Lynne Rienner Publishers.

Bonilla-Silva, E. (2006). Racism without racists: Color-blind racism and the persistence of racial inequality in the United States. Rowman \& Littlefield Publishers.

Brainard, L. A., \& Derrick-Mills, T. (2011). Electronic commons, community policing, and communication: Online police-citizen discussion groups in Washington, DC. Administrative Theory \& Praxis, 33(3), 383-410.

Chiluwa, I., Taiwo, R., \& Ajiboye, E. (2020). Hate speech and political media discourse in Nigeria: The case of the Indigenous People of Biafra. International Journal of media \& cultural politics, 16(2), 191-212.

Crump, J. (2011). What are the police doing on Twitter? Social media, the police and the public. Policy \& internet, 3(4), 1-27.

Chow, H. P. (2012). Attitudes towards Police in Canada: A Study of Perceptions of University Students in a Western Canadian City. International Journal of Criminal Justice Sciences, 7(1).

Cohen, B., \& Chaiken, J. M. (1972). Police background characteristics and performance. New York: Rand.

Dai, M., He, W., Tian, X., Giraldi, A., \& Gu, F. (2017). Working with communities on social media. Online Information Review

Ekenvall, B. (2003). Police attitudes towards fellow officers' misconduct: The Swedish case and a comparison with the USA and Croatia. Journal of Scandinavian Studies in Criminology and Crime Prevention, 3(2), 210 232.

Fyfe, J. J. (1986). The split-second syndrome and other determinants of police violence. Violent transactions, 207225

Esobi, I. C., Lasode, M. K., Anyanwu, C. I., Barriguete, M. F., Okorie, M. A., \& Lasode, D. O. (2021). Food Insecurity, Social Vulnerability, and the Impact of COVID-19 on Population Dependent on Public Assistance/SNAP: A Case Study of South Carolina, USA. Journal of Food Security, 9(1), 8-18.

Glover, K. S. (2007). Police discourse on racial profiling. Journal of Contemporary Criminal Justice, 23(3), 239247.

Gore, L. (2020) Troy University suspends police chief over George Floyd comments. Retrieved on 3 August, 2020 
from comments.html

Guillem, S. M. (2017). Race/ethnicity. In The Routledge Handbook of Critical Discourse Studies (pp. 359-371). Routledge.

Gungor, R., \& Prins, E. (2011). Reproducing Gender Inequality: A Critical Discourse Analysis of a Turkish Adult Literacy Textbook. Research Brief\# 7. Goodling Institute for Research in Family Literacy.

Hayes, T. (2020) Chattanooga police officials weigh in on death of George Floyd. Retrieved on August 3, 2020 from https://www.timesfreepress.com/news/local/story/2020/may/28/chattanooga-police-officials-weighdeath-george-floyd/524035/

Heverin, T., \& Zach, L. (2010). Twitter for city police department information sharing. Proceedings of the American Society for Information Science and Technology, 47(1), 1-7.

Hughey, M. W., \& Daniels, J. (2013). Racist comments at online news sites: a methodological dilemma for discourse analysis. Media, Culture \& Society, 35(3), 332-347.

Hu, X., Rodgers, K., \& Lovrich, N. P. (2018). "We are more than crime fighters": social media images of police departments. Police Quarterly, 21(4), 544-572.

Hu, X., Rodgers, K., \& Lovrich, N. P. (2020). Public preferences regarding police Facebook posts: a macro-level analysis. Police Practice and Research, 21(3), 227-245.

Jackson, J., \& Bradford, B. (2019). Measuring public attitudes towards the police.

Kelly, A. (2014). Managing the risks of public discourse on the New South Wales Police Force Facebook site. Salus Journal, 2(1), 19.

Kendall, S., \& Tannen, D. (2001). 28 Discourse and Gender. The handbook of discourse analysis, 548.

Klein, J. F., Webb, J. R., \& DiSanto, J. E. (1978). Experience with the police and attitude towards the police. Canadian Journal of Sociology/Cahiers canadiens de sociologie, 441-456.

Klockars, C. B. (2000). The measurement of police integrity. US Department of Justice, Office of Justice Programs, National Institute of Justice.

Koplowitz, H. (2020). North Alabama officer placed on administrative leave over George Floyd Facebook post. Retrieved on 3 August, 2020 from https:/www.al.com/news/huntsville/2020/07/north-alabama-officerplaced-on-administrative-leave-over-george-floyd-facebook-post.html

Lersch, K. M., \& Feagin, J. R. (1996). Violent police-citizen encounters: An analysis of major newspaper accounts. Critical Sociology, 22(2), 29-49.

Manning, P. K. (1980). Violence and the police role. The Annals of the American Academy of Political and Social Science, 452(1), 135-144.

McKenith, D. (2020). Mocksville police officer on leave after sharing social media post about George Floyd, rape. Retrieved on 3 August, 2011 from https:/www.wxii12.com/article/mocksville-police-officer-on-leave-aftersocial-media-post $/ 33325552$

Micucci, A. J., \& Gomme, I. M. (2005). American police and subcultural support for the use of excessive force. Journal of criminal justice, 33(5), 487-500.

Mitchell, S. (2020). Greenbrier officer resigns over inappropriate Facebook post. Retrieved on 3 August, 2020 from https://www.robertsoncountyconnection.com/greenbrier-officer-resigns-over-inappropriate-facebookpost/article $996 \mathrm{bc} 1 \mathrm{fc}-\mathrm{a} 118-11$ ea-8ff0-ab5bebc6b90f.html

Morgan, E. (2020). Wayne County police officer fired over George Floyd Facebook post. Retrieved on 3 August, 2020 from https:/www.the-review.com/news/20200529/wayne-county-police-officer-fired-over-georgefloyd-facebook-post

Morin, R., Parker, K., Stepler, R., \& Mercer, A. (2017). Behind the badge. Pew Research Center, 11.

Muir, W. K. (1979). Police: streetcorner politicians. University of Chicago Press.

Neocleous, M. (2000). The fabrication of social order: A critical theory of police power. Pluto Press.

Novak, K. J., \& Ivković, S. K. (2005). Police (mis) behavior: a cross - cultural study of corruption seriousness. Policing: An International Journal of Police Strategies \& Management.

O'Connor, C. D. (2017). The police on Twitter: image management, community building, and implications for policing in Canada. Policing and society, 27(8), 899-912.

Oluwadara, A., Kolapo, B. L., \& Esobi, I. C. (2020). Designing a Framework for Training Teachers on Mobile Learning in Sub-Sahara Africa.

Phillips, S. W., \& Sobol, J. J. (2011). Police attitudes about the use of unnecessary force: an ecological examination. Journal of Police and Criminal Psychology, 26(1), 47-57.

Procter, R., Crump, J., Karstedt, S., Voss, A., \& Cantijoch, M. (2013). Reading the riots: What were the police doing on Twitter?. Policing and society, 23(4), 413-436.

Riley, J. (2020). Metro Corrections officer suspended for 'unacceptable' Facebook posts about George Floyd. Retrieved on 3 August, 2020 from https://www.wdrb.com/in-depth/metro-corrections-officer-suspended-forunacceptable-facebook-posts-about-george-floyd-confederate-flag/article_0a529e9e-bbcd-11ea-9b90- 
b7727e490888.html

Schmelzer, E. (2020). Denver police officer fired for social media post captioned "Let's start a riot." Retrieved on 3 August, 2020 from https://www.denverpost.com/2020/06/02/denver-police-officer-fired-lets-start-a-riotgeorge-floyd-protest/

Schneider, C. J. (2016). Police presentational strategies on Twitter in Canada. Policing and Society, 26(2), 129147.

Terrill, W., \& Mastrofski, S. D. (2002). Situational and officer-based determinants of police coercion. Justice quarterly, 19(2), 215-248.

Tuch, S. A., \& Weitzer, R. (1997). Trends: Racial differences in attitudes toward the police. The Public Opinion Quarterly, 61(4), 642-663.

Turchan, B. (2020). A high-profile police-involved shooting, civil unrest, and officers' perceptions of legitimacy: insights from a natural experiment. Journal of Experimental Criminology, 1-12.

Van Dijk, T. A. (1984). Prejudice in discourse: An analysis of ethnic prejudice in cognition and conversation. John Benjamins Publishing.

Van Dijk, T. A. (2001). 18 Critical discourse analysis. The handbook of discourse analysis, 349-371.

Van Hulst, M. (2013). Storytelling at the police station: the canteen culture revisited. British journal of criminology, 53(4), 624-642.

Waters, G. (2012). Social Media and Law Enforcement: Potential Risks. Retrieved on August 3, 2020 from https://leb.fbi.gov/articles/featured-articles/social-media-and-law-enforcement

Weisburd, D. (2000). Police attitudes toward abuse of authority: Findings from a national study. US Department of Justice, Office of Justice Programs, National Institute of Justice.

Weitzer, R. (2002). Incidents of police misconduct and public opinion. Journal of criminal justice, 30(5), 397-408.

Wodak, R., \& Reisigl, M. (2003). 19 Discourse and Racism. The handbook of discourse analysis, 18, 372.

Wodak, R. (2015). Discrimination via discourse. The Routledge Handbook of Linguistic Anthropology, 366-383.

Worden, R. E. (2015). The causes of police brutality: Theory and evidence on police use of force (Vol. 2, pp. 149204). Routledge, New York, NY, ed. 


\section{APPENDIX I}

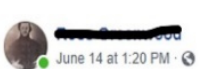

The Treasury Department will honor George Floyd by placing his portrait on the Counterfeit $\$ 20$ Bill.

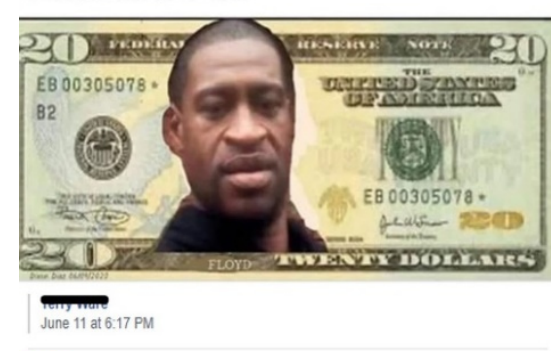

$\rightarrow 04$

$\rightarrow 0_{5}$

$<$

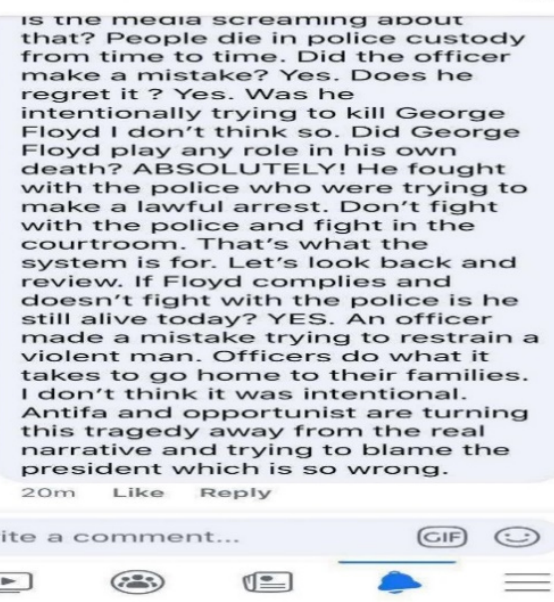

\section{vuviunum. May 27}

There is no need to see more video. There no need to wait to see how "it plays out". There is no need to put a knee on someone's neck for NINE minutes. There IS a need to DO something. If you wear a badge and you don't have an issue with this...turn it in.

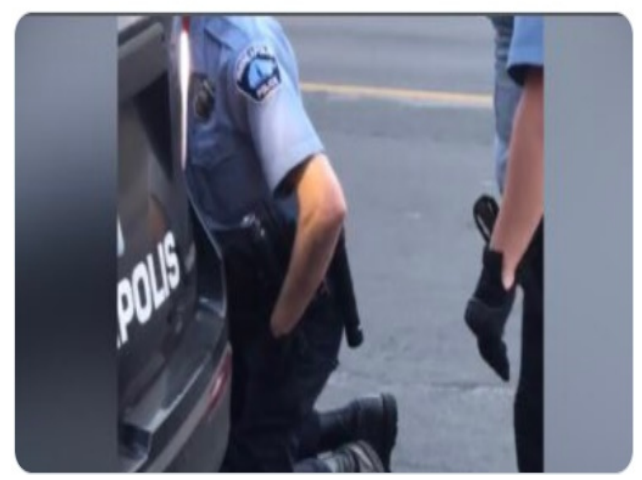

The president wanted some private time to The president wanted some private time to
reflect at the church. He was horrified that the criminals calling themselves protesters had attacked the church and wanted to see the damage himself. It wasn't a prearranged photo op. He wanted to go on
the down-low so no motorcade or any other the down-low so no motorcade or any other over privately to the church. The secret service saw a security issue if the protesters (criminals) saw the president and decided to clear the area. Trump didn't do it, he didn't tell them to tear gas them or shocret service did their job and protected secret service did their job and protected the president was going and spotted him on the WH grounds and tailed him to the church, uninvited and demanded pictures before he left. It wasn't a prearranged to twist everything this man does and make you believe he is wrong for America. He is the only good thing we have going. The left wing democrats wants his tax records so they can show how wich $\$ \$$ he has. I have how paid public servant and don't ning a see his tax records. I would like to see tax records for ordinary people who become millionaires acting as congressmen for a

1 Share

$<$

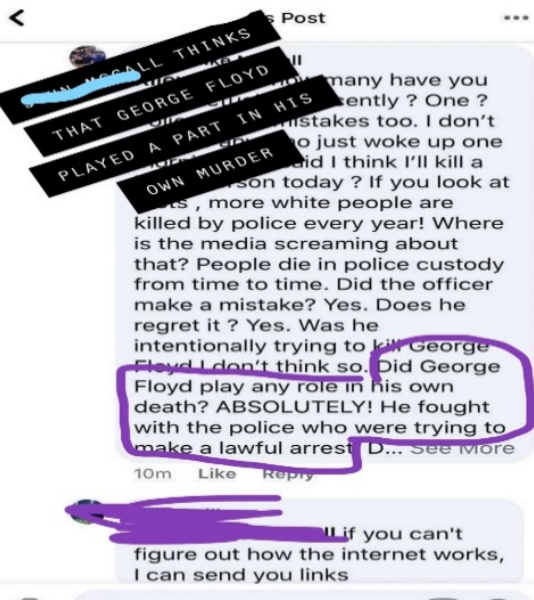

[0]

Write a comment...

(GIF) -(

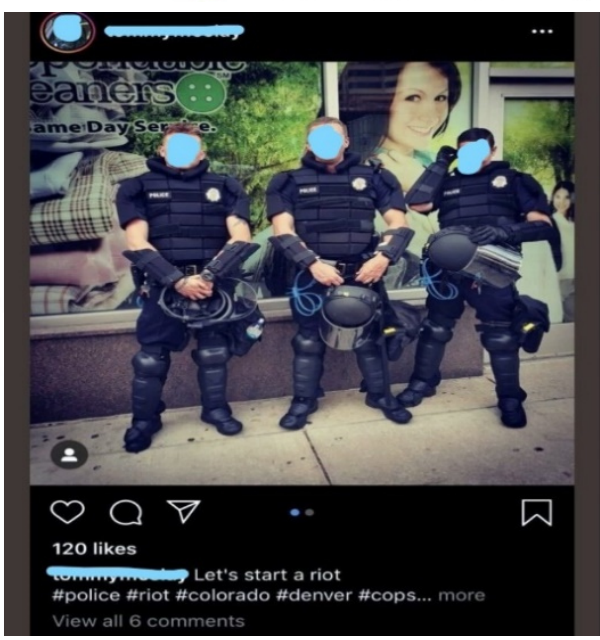

